\title{
Gender wage gaps in Australian workplaces: are policy responses working?
}

\begin{abstract}
Purpose: This paper focuses on the implications of the gender wage gap in Australia, before considering policy responses and their effectiveness at both the government and workplace levels.
\end{abstract}

Methodology: The method concerns an extensive literature review and an examination of secondary data and reports relating to workplace gender equality and data.

Findings: While the gender wage gap in most OECD countries has decreased over time, in Australia the gap has increased, with the largest contributory factor identified as gender discrimination. Consequently it is proposed that current policy responses supporting women in the workplace appear to be ineffective in closing gender wage gaps.

Research implications/limitations: Further research is recommended to identify the impact of gender equality policies on hiring decisions and whether such decisions include an unwillingness to hire or promote women. As findings were based on secondary data, it is recommended that future research include workplace surveys and case studies.

Practical implications: It is suggested that articles such as this one can assist in guiding public policy and workplace decisions on gender wage equality issues, in addition to providing human resource leaders with the information to make better decisions relating to gender equality.

Originality/value: This paper suggests that current policy responses may not only be ineffective in closing the gender wage gap, but may even exacerbate it as employers may avoid hiring women or continue to pay them less than men, due to costs incurred when attempting to meet policy directives.

Paper Type: Research Paper

Keywords: Gender, glass ceiling, equal opportunity, public policy, wage gap, women 


\section{Introduction}

A report by the Equal Opportunity for Women in the Workplace Agency (EOWA) indicated that, in 2012, the Australian gender wage gap stood at 17.4 per cent in favour of male workers (EOWA, 2012). Although this figure is unchanged from 2011, it increased from a low of 14.9 per cent reported in 2004 (which is the same as the gender wage gap reported in 1974). This situation is contrary to most other OECD countries, where gender wage gaps have decreased over time (OECD, 2010a). In addition, the Australian Workplace Gender Equality Agency (Gradstats, 2012) reported that, in 2012, the gender wage gap between male and female university graduates starting salaries more than doubled from 2011, increasing from A \$2,000 to A \$5,000 per annum. Moreover, the Australian Bureau of Statistics (2012a) survey of full-time adult earnings conducted in August 2012 shows that males earned an average of $\mathrm{A} \$ 1490$ per week, while females earned an average of $\mathrm{A} \$ 1188$ per week. This reveals a gap of $\mathrm{A} \$ 302$ per week or 20.3 per cent in favour of males, a gap that has been persistent over the past decade, rising from 17.5 per cent in 2002 (see Table 1).

\section{Table 1 about here}

The extant literature on gender wage differences refers to a number of possible explanations for the wage gaps. The 'glass ceiling' factor is prominent given reduced career progression opportunities for women workers, which appears to be a consistent factor leading to gender income gaps (Storvik and Schone, 2008; Campbell and Vera, 2010; Purcell et al., 2010). Even in feminized industries, such as health and social assistance, large and persistent gender wage gaps have been reported (Jefferson and Preston, 2012). Summers (2013) suggests that there is a 'million dollar penalty' for being a woman in Australia, referring to a 2009 report by the Australian Mutual Provident Society (AMP) and the National Centre for Social and Economic Modelling. This report found that Australian men with children, a bachelor's degree or higher could expect to earn $\mathrm{A} \$ 3.3$ million over their working life, nearly double the amount that women with the same qualifications could expect to earn at $\mathrm{A} \$ 1.8$ million. Conversely, there are suggestions that women voluntarily choose to trade-off their career prospects for domestic duties (Ngo, 2002; Warren, 2004; McDonald et al., 2008). This can prove detrimental to their career and earning prospects, since part-time work and career breaks can hamper career progression, especially for those seeking senior positions. Reinforcing this point, some women may choose domestic duties over a career because they feel discriminated against in the workplace if they attempt to combine both (Aydin et al., 
2011), leading to a self-reinforcing cycle between perceived discrimination and lower career earnings.

In researching the determinants of the gender wage gap in Australia, Cassells (2010) presented the following attributes that account for earning differences; being a woman (60 per cent), industry segregation ( 25 per cent), labour force history ( 7 per cent), vocational qualifications (5 per cent) and firm size ( 3 per cent). This suggests that the largest component of the pay gap is best explained by discrimination against women which corresponds with the findings of the Australia at Work (2010) study. This study reports that the large 'unexplained' pay gap is due to gender in and of itself. Despite awareness raising programs targeting anti-discrimination and equal opportunity in the workplace, it appears that the gender wage gap is widening. According to a recent poll (DCA, 2012) commissioned by the Diversity Council Australia (DCA) and EOWA in 2010, 76 per cent of Australians agree that steps should be taken to close the gender wage gap.

To date there have been significant public policy reforms in Australia to reduce the gender wage gap. For example, Fair Work Australia (FWA) introduced Equal Remuneration Orders in 2009, the National Employment Standard in 2010, the Gender Equality in 2010, and the Paid Parental Leave Scheme in 2011. However, the gender wage gap remained unchanged from 2011 to 2012 at 17.4 per cent (EOWA, 2012). More importantly, the gap between university graduates more than doubled from 2011 to 2012, increasing from $A \$ 2,000$ to A \$5,000 per annum (Gradstats, 2012). This shows that the reforms have so far failed to make an impact, and in the case of university graduates, the gap has actually increased. In order to explore these issues, this article reviews relevant literature and data concerning potential explanations for the gender wage gaps. The article concentrates on glass ceilings and glass escalators, workplace discrimination, reduced employment status and potential career barriers. It concludes with a discussion concerning the implications of gender inequality within the Australian workforce, current initiatives and their effectiveness as well as some recommendations with regard to how the gap may be reduced.

\section{What are the reasons for the gender wage gap?}

The Workplace Gender Equality Agency (2013) suggested six reasons behind the persistence of the gender wage gap in Australia, being 1) Gender discrimination, 2) Career breaks, 3) Industrial segregation, 4) Occupational segregation, 5) Undervaluation of women's skills, and 
6) Pay setting methods. Gender discrimination in the workforce is not only linked to pay differences but to employment practices such as hiring, promotion and access to training. Career breaks affect pay as child bearing imposes a penalty on women in terms of career and salary progression, and in turn, on their ability to generate retirement (pension) incomes linked to employment continuity. Industrial segregation is also an issue as women dominate lower paid service work in areas such as retail, care and hospitality and men dominate higher paid jobs in areas such as mining and construction. This also occurs with occupational segregation where men dominate leadership and senior management (and higher paid) positions. Women's workforce skills are frequently undervalued as they perform many of the personal customer and caring roles (e.g. in retail and health), and in the Australian context, this has been reinforced by an institutional wage system that has underrated those occupations that are primarily dominated by women. Pay setting methods also affect women's pay, as many women are in occupations or industries that are dependent on awards, and thus are not in a position (nor do they have the power) to bargain with employers.

Given the aforementioned reasons suggested by the Workplace Gender Equality Agency (2013) for the existence of the gender wage gap in Australia, they found that approximately one-third could be explained by a combination of factors. These included: the industry or sector, firm size, bargaining arrangements (especially individual contracts) and the location of employment (with differences between states, urban and regional locations). However, two-thirds of the gap was attributed to gender. That is, being a female employee in Australia can result in an average pay difference of about 12 per cent after accounting for other possible determinants of pay gaps. For this paper, three factors are addressed that reportedly contribute to the gender wage gap - recruitment practices, the costs associated with part-time work, and the gendering of leadership positions. These three factors can also be targeted for action related to reducing the gender wage gap.

\section{Graduate starting wage inequality}

The issue of increasing gender wage gaps and commencing salaries in Australia is starkly illustrated by the Gradstats (2012) report that is produced by the Australian Government's Workplace Gender Equality Agency. This report indicates that the median for full-time commencing salaries for male university graduates increased to $\mathrm{A} \$ 55,000$ in 2012 from A $\$ 52,000$ in the preceding year, while that of their female counterparts remain unchanged at 
$\mathrm{A} \$ 50,000$. This amounts to a 250 per cent annual increase in the pay gap from $A \$ 2,000$ to A \$5,000 per annum, with men earning 10.0 per cent more than women. While this gap is not as pronounced as the 17.4 per cent gap reported for the general workforce (EOWA, 2012), it is still problematic, because the frequently reported structural issues - such as career breaks and part-time work do not explain this gap. Also, the 'glass ceiling' does not apply in such cases as the report refers to entry-level jobs (i.e. graduate and not postgraduate level), which also makes the wage diminishing effect of women's caring responsibilities unlikely. Furthermore, the data only covers full-time work, so the effect of lower wages in female dominated casual and part-time work is not included. According to the report, the sector with the widest gap in favour of men is architecture and building at 20.9 per cent, followed by Dentistry at 18.6 per cent, Optometry at 9.3 per cent, and Law at 8.5 per cent (Table 2). The largest annual increases were recorded in the field of Dentistry and Optometry. These two sectors also pay substantially more than the others and the gender wage gap is more pronounced. However, female graduates earned slightly more than men in seven out of the 23 occupations listed. Only three occupational categories had no gender wage gap evident in the starting salaries: Education, Humanities, and Medicine. Thus, on average, females in Australia can expect to start their careers on lower commencing salaries than men within the same occupation.

\section{Table 2 about here}

\section{Glass ceilings and glass escalators}

The Australian Bureau of Statistics (2011a) reports that only three per cent of CEOs among the top 200 Australian Securities Exchange (ASX) companies are female. Eagly and Carli (2007) also highlight the paucity of women in senior management, with women representing only two per cent of CEOs among Fortune 500 companies, describing how, to get to the top, women have to navigate through a 'labyrinth of leadership'. Evidence suggests that women are frequently confronted by an invisible obstacle that prevents them from rising to leadership status known as the 'glass ceiling' (Storvik and Schone, 2008; Campbell and Vera, 2010; Purcell et al., 2010), while men (particularly those in female dominated professions) have been found to be more likely to ascend into management positions by way of a 'glass escalator' (Williams, 1992). Maume (1999) supports the notion that a glass escalator exists for working men reporting that, when there is a higher percentage of women in the workplace 
this increases the chances that men are promoted to management positions, but decreases the chances that women are promoted to such positions.

The EOWA (2012) findings have led commentators such as Horin (2010) to state that Australia's performance with regard to female representation was disgraceful at 8.3 per cent female representation on boards, especially in comparison with Norway at 44.2 per cent (having risen from 6.8 per cent in 2002) and the Fortune 500 companies at 15.3 per cent. She noted that the Philippines, Thailand, South Africa and Turkey appear to be better performers than Australia with regard to this issue. Further, the Gender equality in the Workplace report commissioned by the Australian Human Resources Institute (AHRI, 2011) found that from the 950 institute members surveyed, one in five respondents (21.79 per cent) believed recruitment and selection practices in their organisation were not designed to minimize gender bias, and nearly one in three (30.63 per cent) believed performance management and promotion practices were similarly flawed. Additionally, 65.13 per cent of respondents believed the gender mix at the management and leadership levels in their organisation was not appropriate, and 69.72 per cent believe the mix was inappropriate at board level.

\section{Part-time employment and its costs}

The Australian Bureau of Statistics data (2011b) shows that female workers dominate parttime work and part-time casual work, which are generally not career jobs, consequently they have limited advancement opportunities compared to those in full-time work. Preston and $\mathrm{Yu}$ (2013) recently found that part-time workers earned 6.9 per cent less than full-time workers, even after controlling for qualifications, experience, gender, industry, method of pay setting, and casual status. This shows that the growth in part-time female employment is a contributory factor explaining the widening gender wage gap in Australia. The OECD (2010b, p.215) reports that Australia ranks third highest among member countries in terms of the proportion of the workforce in part-time employment. In common with other OECD economies, women dominate part-time work (Crompton, 2002; Ngo, 2002; Warren, 2004; Sheridan, 2004; Pilcher, 2007; Tomlinson, 2007; McDonald, Bradley, and Brown, 2008; Atkinson and Hall, 2009). In particular, Tomlinson (2007) found that part-time work is highly gendered and often low-status, which can have serious consequences for women's economic independence, financial security, and quality of working life. Similarly, Sirianni and Negrey (2000) point out that part-time female employees may be limited to jobs that pay poorly, provide few benefits and offer few opportunities to gain new skills. The OECD 
report and other research data suggests that working mothers may accept inferior terms and conditions to accommodate their domestic obligations (Brockbank and Airy, 1994). Consequently, a trade-off exists in that flexibility gains by employees may be lost in the reduced terms and conditions of their employment (Negrey 1990; Ferber, O'Farrell, and Allen, 1991; Brockbank and Airey, 1994). The findings presented in Table 3 are drawn from the Australia at Work (2009) data and show that the majority of women with dependent children occupied part-time positions (56.6 per cent), with most of these part-time positions being permanent, indicating an ongoing commitment to part-time roles balanced with child care responsibilities. Conversely, men with dependent children strongly dominated permanent full-time roles ( 90.7 per cent), indicating that the majority undertake the role of career-oriented breadwinner.

\section{Table 3 about here}

\section{Addressing the gender wage gap at the policy level}

Although there has been an active policy program to address gender equality in Australian workforces, it has not yet served to lessen the gender wage gap. Recent policy developments concern occupational wage cases and the provision of paid parental leave. Whittard and Burgess (2007) point out that the traditional way to reconcile work and care is through parttime work. However, the OECD (2010c, p.2) reported that Australian part-time workers have poor financial incentives to move into full-time work because benefits in the welfare system are means-tested and 'clawed back' as incomes rise. This implies that the popularity of parttime work in Australia's employment structure can be attributed to a lack of work and family reconciliation in Australian industrial agreements (Burgess, Henderson, and Strachan 2007), which can be expected of a liberal market economy with an emphasis on market-based resource allocation (Connell, Burgess, and Hannif, 2008). However, conditions should change as a result of recent policy reforms in Australia such as the National Employment Standard, which enables employers to introduce more flexible working arrangements and leave for parents and carers (National Employment Standard, 2010). Also the Australian Government's Paid Parental Leave scheme, which took effect from 1 January 2011, provides working parents with 18 weeks of paid parental leave at a minimum wage (Paid Parental Leave Scheme 2011). Since 2009, there has been further policy development relating to women and work, signifying a reframing of the policy debates around women, work, and 
family in Australia (Baird and Williamson, 2009, 2010, 2011; Baird, Williamson, and Heron, 2012).

\section{Addressing the gender wage gap at the workplace level}

In order to mitigate the gender wage gap, there are steps being put into place by statutory bodies (e.g. Fair Work Australia and the Workplace Gender Equality Agency) to address pay and other gender inequalities in the workplace. In others, such as the group that appear to be under the most financial and work related strain, that is female single-parents, solutions are not readily evident. As discussed previously, this may be because single-parent females often opt to undertake part-time work but, if they are working part-time due to child care responsibilities, potentially they are not only paid less, they also have to take on more child care responsibility than two parent families do. However, this situation is not unique to Australia, being recognized as problematic in many other westernized countries. Other research has noted that working mothers appear to have been particularly discriminated against in terms of wages (Budig and England, 2001; Cuddy, Fiske, and Glick, 2004; Blades and Rowe-Finkbeiner, 2006; Gungor and Biernat, 2009; Ortiz and Roscigno, 2009). In countries where substantial pay gaps exist, there are a number of initiatives that human resource directors, governments, trade unions, and employer organisations can introduce. That said, it has been argued that managing diversity takes a more positive stance than the preventative laws that have been introduced through equal opportunity. Diversity management as part of an organisation's human resource strategy concerns the business case for improved organisational performance (Pilch, 2006), which may also involve the need for organisational culture change (Singh, 2002).

The Diversity Council Australia (DCA), in consultation with members, and in response to the 2012 WAGE act, recommended measures to progress gender equality, which includes the provision of case studies available through the DCA website, advocating on behalf of DCA members to government, and the provision of expert advice from DCA staff (DCA, 2013). The recent move by ASX to implement guidelines from June 2010 on reporting by listed companies with regard to diversity requirements has been designed to provide greater transparency on the processes that boards adopt in board member selection and succession planning. These processes include the steps ASX listed companies take to ensure that they have a diverse range of candidates for positions, the appropriate gender mix on boards, and a requirement to establish a diversity policy, which include[s] requirements for the board to 
establish measurable objectives for achieving gender diversity'. Diversity is defined broadly to include gender, age, ethnicity and cultural background, although the recommendations lean strongly towards gender diversity (ASX, 2010).

\section{Conclusion and recommendations}

Clearly, the evidence provided here indicates that the gender wage gap persists in Australia, despite the policy responses that have been introduced to address it. Current policy responses encompass issues such as work flexibility, paid parental leave, pay transparency and mandatory reporting. While these policies address gender equality in Australian workforces, they do not yet appear to have lessened the gender wage gap. Rather, they have the potential to exacerbate the wage gap if employers consequently avoid hiring women, or choose to pay women less due to costs incurred covering parental leave entitlements and more. Additionally, current policy initiatives do not cover the more than doubling of the gender wage gap among university graduates (Gradstats, 2012) because the report only samples fulltime work and fresh graduate (not postgraduate) positions, which are largely unaffected by issues such as work flexibility, parental leave, and 'glass ceilings'. Given this review of current data on the topic, it is argued that one of the largest contributions to the gender wage gap was found to be gender discrimination. Thus, despite the array of remedial policy actions, which include anti-discrimination and equal opportunity legislation, the pay gap has remained and women are still faced with inferior pay, conditions, and prospects.

Various authors, such as Budig (2002), Goldberg et al., (2004), Sumner and Niederman (2004), Gorman (2006), and Purcell et al., (2010) point to the female pay disadvantage that exists because women tend to work in lower-paying, feminized occupations, and they are paid less for the same work, or because male workers are favoured. This situation can occur even when men are the numerical minority in the workplace, due to 'traditional' workplace cultures and women apparently needing to work harder than men to achieve the same parity at work. While the majority of research attributes gender discrimination against women to income inequity, there may also be a voluntary choice factor contributing to the inequalities experienced by women. The OECD (2010a) and other research data suggests that working mothers may accept inferior terms and conditions to accommodate their domestic obligations (Brockbank and Airey, 1994). Consequently, a trade-off exists in that flexibility gains by 
employees may be lost in the terms and conditions of employment (Negrey, 1990; Ferber, O'Farrell, and Allen, 1991; Brockbank and Airey, 1994).

Action can be undertaken at many levels to support gender equality in the labour market. The strategies being enacted by ASX, FWA, EOWA and others indicate that some progress is being made. Turning to Norway, Nergaard (2010) claimed that the Norwegian government needs to "find ways to fight involuntary part-time work" and this challenge could also be directed at the Australian government and the governments of other countries. However, the question remains as to whether part-time work is undertaken by women as a matter of choice or necessity (i.e. they would prefer full-time work). That said, there are two key concerns; firstly that women appear to be underpaid when compared to men, and secondly, that the 16 to 17 per cent of single-parent households in Australia, of which 85 per cent are headed by women, may not be receiving the support they require to work full-time (and receive higher pay). As for policy reforms that support women in the workplace, the problem is that the more women are protected in the workplace, the more employers may hire men to avoid the impact of such policies, given the likelihood that many women may eventually take maternity and child care leave, and then adopt roles as primary carers, which could be perceived as detrimental to workplace productivity. These factors parallel perspectives that, current policy reforms can potentially exacerbate the wage gap and, in-part, explain the more than doubling of the pay gap between male and female graduates (Gradstats, 2012), which has coincided with a surge of policy relating to women and work since 2009 (Baird et al., 2012). Hence, further research is recommended, which could be undertaken by surveying employers or conducting workplace based case studies. Such empirical research could be conducted to identify the impact of the policies discussed to date on hiring decisions and whether such decisions include an unwillingness to hire or promote women, and whether employers deliberately pay women less due to other costs incurred in relation to the introduction of various diversity policies. 


\section{TABLES}

Table 1: Mean weekly earnings in full-time jobs

\begin{tabular}{lccc}
\hline Year & Males $\mathbf{( A \$ )}$ & Females $(\mathbf{A} \mathbf{\$})$ & Pay Gap $(\boldsymbol{\%})$ \\
\hline 2002 & 921 & 760 & 17.5 \\
2003 & 967 & 790 & 18.3 \\
2004 & 997 & 819 & 17.9 \\
2005 & 1054 & 856 & 18.8 \\
2006 & 1131 & 910 & 19.5 \\
2007 & 1216 & 971 & 20.1 \\
2008 & 1251 & 1007 & 19.5 \\
2009 & 1319 & 1063 & 19.4 \\
2010 & 1369 & 1093 & 20.2 \\
2011 & 1414 & 1134 & 19.8 \\
2012 & 1490 & 1188 & 20.3 \\
\hline
\end{tabular}

Source: Australian Bureau of Statistics (2012a)

Table 2: Field of education where male median graduate starting salaries exceeded female median graduate starting salaries

\begin{tabular}{|c|c|c|c|c|}
\hline Industry & $\begin{array}{c}\text { Males } \\
(\mathrm{A} \$, 000) 2012\end{array}$ & $\begin{array}{c}\text { Females } \\
(\mathrm{A} \$, 000) 2012\end{array}$ & $\begin{array}{c}\text { Males } \\
(\mathrm{A} \$, 000) 2011\end{array}$ & $\begin{array}{c}\text { Females } \\
(\mathrm{A} \$, 000) 2011\end{array}$ \\
\hline $\begin{array}{l}\text { Architecture } \\
\text { and building }\end{array}$ & 52 & 43 & 50 & 43 \\
\hline Dentistry & 92 & 77.6 & 80 & 75 \\
\hline Optometry & 82 & 75 & 72 & 70 \\
\hline Law & 55 & 50.7 & 52 & 50 \\
\hline $\begin{array}{l}\text { Economics, } \\
\text { business }\end{array}$ & 50 & 47 & 50 & 45 \\
\hline Art and design & 42.5 & 40 & 42 & 40 \\
\hline Accounting & 50 & 48 & 48 & 46 \\
\hline Mathematics & 58.1 & 56 & 55 & 55 \\
\hline $\begin{array}{l}\text { Veterinary } \\
\text { science }\end{array}$ & 46 & 45 & 43 & 45 \\
\hline $\begin{array}{l}\text { Paramedical } \\
\text { studies }\end{array}$ & 53 & 52 & 52 & 50 \\
\hline Social work & 50.9 & 50 & 49 & 50 \\
\hline Psychology & 49.5 & 49 & 50 & 47 \\
\hline $\begin{array}{l}\text { Agricultural } \\
\text { science }\end{array}$ & 50.5 & 50 & 45 & 46 \\
\hline
\end{tabular}


Table 3. Employees classified by employment status, gender, and dependent children

\begin{tabular}{llccccc}
\hline & & \multicolumn{3}{c}{ Employment Status } \\
Dependent & Gender & Casual & Permanent & Casual & Permanent \\
\cline { 2 - 6 } & & PT & PT & FT & FT & All \\
\hline With & Males & 35 & 35 & 44 & 1110 & 1224 \\
dependent & & $(2.9 \%)$ & $(2.9 \%)$ & $(3.6 \%)$ & $(90.7 \%)$ & $(100 \%)$ \\
children & Females & 181 & 460 & 21 & 472 & 1134 \\
& & $(16.0 \%)$ & $(40.6 \%)$ & $(1.9 \%)$ & $(41.6 \%)$ & $(100 \%)$ \\
Without & Males & 174 & 81 & 69 & 869 & 1193 \\
dependent & & $(14.6 \%)$ & $(6.9 \%)$ & $(5.8 \%)$ & $(72.8 \%)$ & $(100 \%)$ \\
children & Females & 285 & 228 & 33 & 702 & 1248 \\
& & $(22.8 \%)$ & $(18.3 \%)$ & $(2.6 \%)$ & $(56.3 \%)$ & $(100 \%)$ \\
\hline
\end{tabular}

Source: Australia at Work (2009) 


\section{References}

Atkinson, C. and Hall, L. (2009), The Role of Gender in Varying Forms of Flexible Working, Gender, Work and Organization, 16, 650-666.

Austen, S., Jefferson, T., Preston, A. and Seymour, R. (2008) Gender Pay Differentials in Low-Paid Employment. Australian Fair Pay Commission, Research Report No. 3/9, October.

Australia at Work (2009), Australia at Work Data Set, Workplace Research Centre, Sydney University

Australia at Work (2010), Gender Earnings, Fact sheet No.7, Workplace Research Centre, Sydney University, viewed 16 February 2013,

http://www.australiaatwork.org.au/assets/07.\%20Gender\%20pay\%20gap\%202011.pdf

Australian Bureau of Statistics [ABS] (2011a), Gender Indicators. Catalogue 4125.0. Canberra: ABS.

Australian Bureau of Statistics [ABS] (2011b), Employee Earnings and Hours. Catalogue 6306.0. Canberra: ABS.

Australian Bureau of Statistics [ABS] (2012a) Employee Earnings, Benefits, and Trade Union Membership. Catalogue 6310.0. Canberra: ABS.

Australian Human Resource Institute [AHRI], (2011), Gender Equity in the Workplace, HR Pulse Research Report.

Australian Securities Exchange (2010), ASX corporate governance council corporate governance principles and Recommendations Summary of 30 June 2010 amendments, viewed 31 January 2012, www.asx.com.au/documents/about/cg_comparative_table_june_2010.pdf

Aydin, N., Graupmann, V., Fischer, J., Frey, D., and Fischer, P. (2011), My role is my castle-The appeal of family roles after experiencing social exclusion, Journal of Experimental Social Psychology, 47, 981-986.

Baird, M. and Williamson, S. (2009), Women, Work and Industrial Relations in 2008, Journal of Industrial Relations, 51, 331-346.

Baird, M. and Williamson, S. (2010), Women, Work and Industrial Relations in 2009, Journal of Industrial Relations, 52, 355-369.

Baird, M. and Williamson, S. (2011), Women, Work and Industrial Relations in 2010, Journal of Industrial Relations, 53, 337-352.

Baird, M., Williamson, S., and Heron, A. (2012), Women, Work and Industrial Relations in 2011, Journal of Industrial Relations, 54, 326-343.

Blades, J., and Rowe-Finkbeiner, K. (2006), The motherhood manifesto: What Americas moms want and what to do. Nation Books, New York. 
Brockbank, A. and Airey, Y. (1994), Women Managers in the Retail Industry, International Journal of Retail and Distribution Management, 22, 3-12.

Budig, M. and England, P. (2001), The Wage Penalty for Motherhood, American Sociological Review, 66, 204-25.

Budig, M. (2002), Male Advantage and the Gender Composition of Jobs: Who Rides the Glass Escalator? Social Problems, 49, 258-277.

Burgess J., Henderson, L., and Strachan, G. (2007), Work and family balance through equal employment opportunity programmes and agreement making in Australia, Employee Relations, 29, 415-430.

Campbell, K. and Vera, A. (2010), Female board appointments and firm valuation: short and long-term effects, Journal of Management and Governance, 14, 37-59.

Cassells, R. (2010), The gender wage gap in Australia: What it costs us, why it's still here and will it ever go? Women and Industrial Relations Conference, Darwin, 12-13 August

Connell, J., Burgess, J., and Hannif, Z. (2008), Job Quality: What does it Mean, What does it Matter? Comparisons between Australia and the UAE, International Journal of Employment Studies, 16, 59-78.

Crompton, R. (2002), Employment, flexible working and the family, British Journal of Sociology, 53, 537-58.

Cuddy, A., Fiske, S., and Glick, P. (2004), When professionals become mothers, warmth doesnt cut the ice, The Journal of Social Issues, 60, 701-718.

Diversity Council Australia [DCA] (2012), Fair Work Australia ruling an historic step towards gender pay equity, viewed 18 January 2013, www.dca.org.au

Diversity Council Australia [DCA] (2013), Employers want input on implementing gender equality reforms, viewed 27 May 2013, www.dca.org.au

Eagly, A. and Carli, L. (2007), Through the labyrinth: The truth about how women become leaders, Harvard Business School, Boston.

Equal Opportunity for Women in the Workplace Agency [EOWA] (2012), Gender wage gap Statistics, February 2012, viewed 28 September 2012, www.eowa.gov.au/Information_Centres/Resource_Centre/Statistics/Gender_Pay_Gap_Fact_ Sheet_May_2012.pdf

Ferber, M., O'Farrell, B., and Allen, L. (1991), Work and Family: Policies for a Changing Work Force, National Academy Press, Washington, DC.

Goldberg, C., Finkelstein, L., Perry, L., and Konrad, A. (2004), Job and industry fit: The effects of age and gender matches on career progress outcomes, Journal of Organizational Behavior, 25, 807-829. 
Gorman, E. (2006), Work Uncertainty and the Promotion of Professional Women: The Case of Law Firm Partnership, Social Forces, 85, 865-90.

Gradstats (2012), Gradstats- starting salaries, Workplace Gender Equality Agency, viewed 28 January 2013, www.wgea.gov.au/Information_Centres/Resource_Centre/Statistics/2013-0107_GradStats_factsheet.pdf

Gungor, G. and Biernat, M. (2009), Gender Bias or Motherhood Disadvantage? Judgments of Blue Collar Mothers and Fathers in the Workplace, Sex Roles, 60, 232-246.

Horin, A. (2010), Companies rush to get on board with gender guidelines, viewed 31 January 2012 ,

www.smh.com.au/opinion/companies-rush-to-get-on-board-with-gender-guidelines20101008-16bwj.html

Jefferson, T. and Preston, A. (2012), Labour Markets and Wages in Australia in 2011, Journal of Industrial Relations, 54, 293-311

Koeske, G. and Krowinski, W. (2004), "Gender-Based Salary Inequity in Social Work: Mediators of Gender's Effect on Salary". Social Work, 49, 309-317.

Maume, D. (1999), Glass Ceilings and Glass Escalators: Occupational Segregation and Race and Sex Differences in Managerial Promotions, Work and Occupations, 26, 483-509.

McDonald, P., Bradley, L. and Brown, K. (2008), Visibility in the workplace: still an essential ingredient for career success? The International Journal of Human Resource Management, 19, 2198-2295.

National Employment Standards (2010) Fair Work Ombudsman, Australian Government, viewed 18 January 2013,

www.fairwork.gov.au/employment/national-employment-standards/pages/default.aspx

Negrey, C. (1990), Contingent Work and the Rhetoric of Autonomy, Humanity and Society, $14,16-33$.

Nergaard, K. (2010), Addressing the gender wage gap: Government and social partner actions - Norway, viewed 31 January 2012, www.eurofound.europa.eu/eiro/studies/tn0912018s/no0912019q.htm

Ngo, H. (2002), Part-time employment in Hong Kong: a gendered phenomenon?, The International Journal of Human Resource Management, 13, 361-377.

OECD [Organization for Economic Cooperation and Development] (2010a), Gender Brief, OECD Social Policy Division, Paris: OECD.

OECD [Organization for Economic Cooperation and Development] (2010b) OECD Employment Outlook 2010, Paris: OECD. 
OECD [Organization for Economic Cooperation and Development] (2010c), OECD Employment Outlook 2010 - How does Australia Compare?, Paris: OECD.

Ortiz, S.Y. and Roscigno, V.J. (2009), Discrimination, Women, and Work: Processes and Variations by Race and Class, Sociological Quarterly, 50, 336-359.

Paid Parental Leave Scheme (2011) Australian Government, viewed 18 January 2013, www.fahcsia.gov.au/our-responsibilities/families-and-children/programs-services/paidparental-leave-scheme

Pilch, T. (2006), Diversity and Economy, London: Smith Institute.

Pilcher, K. (2007), A Gendered "Managed Heart"? An Exploration of the Gendering of Emotional Labour, Aesthetic Labour, and Body Work in Service Sector Employment, Reinvention: a Journal of Undergraduate Research, 1, 1-13.

Preston, A. and Yu, S. (2013), Understanding the Part time/Full time Wage gap in Australia. Paper presented at the AIRAANZ Conference, Perth, February.

Purcell, D., MacArthur, K.R., and Samblanet, S. (2010), Gender and the Glass Ceiling at Work, Sociology Compass, 4, 705-717.

Sheridan, A. (2004), Chronic Presenteeism: The Multiple Dimensions to Mens Absence from Part-Time Work, Gender, Work and Organization, 11 207-225.

Singh, V. (2002), Managing Diversity for Strategic Advantage, London: Council for Excellence in Management and Leadership.

Sirianni, C. and Negrey, C. (2000), Working Time as Gendered Time, Feminist Economics, 6,59-76.

Storvik, A. E. and Schone, P. (2008), In search of the glass ceiling: gender and recruitment to management in Norways state bureaucracy, The British Journal of Sociology, 59, 729-755.

Sumner, M., and Niederman, F. (2004), The impact of gender differences on job satisfaction, job turnover, and career experiences of systems professionals, Journal of Computer Information Systems, 44, 29-40.

Summers, A. (2013) Gender wage gap still a disgrace, Sydney Morning Herald, viewed 18 January 2013

www.smh.com.au/opinion/gender-pay-gap-still-a-disgrace-20130104-2c8o6.html

Warren, T. (2004), Working part-time: achieving a successful "work-life" balance?, The British Journal of Sociology, 55, pp.99-122.

Whittard, J. and Burgess J. (2007), Working-time flexibility and full-time work in a retail banking organisation, Labour and Industry, 17: 119-141.

Williams, C. (1992), The glass escalator: Hidden advantages for men in the female professions, Social Problems, 39, 253-267. 
Workplace Gender Equality Agency [WGEA] (2012), WGE Act at a glance, viewed 16 February 2013,

www.wgea.gov.au/About_WGEA/The_Act/Branded_act_at_a_glance_wgea.pdf

Workplace Gender Equality Agency [WGEA] (2013), Behind the Gender Wage Gap.

www.wgea.gov.au Accessed May 15, 2013 